\title{
Pemodelan Bisnis Berbasis UML Dalam Rangka Rekayasa Ulang Perangkat Lunak Pada Unit Usaha Kecil dan Menengah Koperasi Wanita Setia Bhakti Wanita Jawa Timur
}

\author{
Teguh Sutanto $^{1}$ Norma Ningsih ${ }^{2}$ Endra Rahmawati ${ }^{3}$ \\ Program Studi Sistem Informasi, Universitas Dinamika, Surabaya \\ Email: teguh@dinamika.ac.id ${ }^{\mathbf{1}}$,norma@dinamika.ac.id² ${ }^{\mathbf{2}}$,rahmawati@dinamika.ac.id ${ }^{3}$
}

\begin{abstract}
Abstrak: Permasalahan utama Koperasi Wanita Setia Bhakti Wanita Jawa Timur pada proses rekayasa ulang perangkat lunak adalah adanya pemodelan bisnis yang dapat digunakan sebagai dasar penentuan spesifikasi kebutuhan system baru. Berdasarkan permasalahan di atas, maka penelitian ini mengusulkan pemodelan bisnis menggunakan UML yang menghasilkan diagram use case bisnis dan diagram aktivitas yang akan digunakan sebagai referensi dalam rekayasa ulang system Unit UKM. Proses pemodelan bisnis dilakukan dengan cara sebagai berikut:pencarian actor, pencarian use case bisnis, pencarian relasi dan pembuatan diagram use case bisnis dan diagram aktivitas. Penelitian ini menunjukan adanya 11 aktor, 22 use case bisnis dan 22 diagram aktivitas yang dapat digunakan sebagai referensi Tim Pengembang dalam merancang dan membangun ulang system UKM.
\end{abstract}

Kata Kunci: UML, Use Case Business, Software Reengineering

\begin{abstract}
The main problem of the Women's Cooperative Setia Bhakti Wanita East Java in the software reengineering process is the existence of a business model that can be used as a basis for determining the specifications for the new system requirements. Based on the problems above, this study proposes business modeling using UML which produces business use case diagrams and activity diagrams that will be used as references in reengineering the SME Unit system. The business modeling process is carried out in the following ways: actor search, business use case search, relationship search and business use case diagramming and activity diagrams. This study shows that there are 11 actors, 22 business use cases and 22 activity diagrams that can be used as a reference for the Development Team in designing and rebuilding the SME system..
\end{abstract}

Keywords: UML, Use Case Business, Software Reengineering

\section{PENDAHULUAN}

Unit Usaha Kecil dan Menengah (Unit UKM) merupakan salah satu unit layanan anggota dari Koperasi Wanita Setia Bhakti Wanita Jawa Timur. Koperasi dapat diartikan sebagai kumpulan orang atau badan yang saling bekerja secara bersama-sama [1]. Proses bisnis utama Unit UKM adalah melayani penyimpanan uang dari anggota dan peminjaman dengan berbagai skema ke anggota [2]. Untuk melaksanakan proses bisnis tersebut, Unit UKM sudah menggunakan sistem terkomputerisasi yang disebut dengan System UKM. System
UKM adalah aplikasi desktop yang dibangun menggunkan Microsoft Visual Foxpro 9.0 dengan database file berekstensi $*$.dbf.

Perkembangan jumlah anggota Unit UKM yang semakin banyak dan diikuti transaksi simpanan dan pinjaman yang beragam, serta kondisi pandemi saat ini yang mengharuskan kerja secara online maka Pengurus koperasi mencanangkan untuk melakukan pembuatan System UKM yang baru. System UKM yang lama ternyata belum mampu untuk bisa mengikuti kebutuhan transaksi online sehingga System UKM yang baru memiliki kebutuhan 
Teguh Sutanto, dkk/ Journal of Technology and Informatics (JoTI), Vol.2, No.2, April 2021, Hal 5664

non fungsional bisa diakses secara online melalui jaringan internet. System UKM yang baru diharapkan akan dapat mengurangi dampak pandemi pada koperasi [3] [4].

Berdasarkan hal di atas maka Pengurus Koperasi menugaskan Unit Electronic Data Processing (EDP) untuk mengembangkan System UKM baru dengan mengadopsi apa yang masih relevan dari sistem yang lama dan menambahkan fitur yang belum ada tetapi dibutuhkan Unit UKM pada masa saat ini. Proses pengembangan perangkat lunak berdasarkan perangkat lunak yang sudah ada sebelumnya disebut sebagai Rekayasa Ulang Perangkat Lunak [5].

Dalam rangka melakukan proses rekayasa ulang system tersebut maka dibutuhkan proses pemodelan bisnis [6] [7]. Pemodelan Bisnis berdasarkan referensi [6] dan [7] menunjukkan bahwa pemodelan bisnis dapat memanfaatkan visual modelling menggunakan notasi UML (support Booch'93) dengan bantuan Software Rational Rose. Namun, terdapat beberapa kekurangan, diantaranya (1) Rational Rose adalah software lama yang dibuat tahun 1981 dan dikembangkan oleh IBM sejak 1994 (2) Membutuhkan plugin tambahan JDK untuk melakukan generate code dan import beberapa file .mdl untuk menjalakannya (3) Versi terbaru pada website IBM adalah 7.0.0.4 pada tahun 2018. Berdasarkan pertimbangan tersebut, pemodelan bisnis pada penelitian ini menggunakan aplikasi lain yaitu Astah UML.

Permasalahan yang ada pada Koperasi

Wanita Setia Bhakti Wanita adalah bagaimana merumuskan pemodelan bisnis yang dapat digunakan sebagai acuan dalam proses rekayasa ulang system pada Unit UKM. Berdasarkan permasalahan di atas maka penelitian ini mengusulkan pemodelan bisnis menggunakan Unified Modeling Language (UML). Dengan pemodelan bisnis maka tim pengembang (Unit EDP) dapat merumuskan spesifikasi kebutuhan system dan fitur-fitur apa saja yang harus ada pada sistem yang baru.

\section{METODE}

\section{Pemodelan Bisnis Dengan UML}

Model dalam paradigma pengembangan perangkat lunak adalah abstraksi dari sebuah system [8]. Pemodelan bisnis dapat diartikan sebagai abstraksi dari proses bisnis sebuah organisasi. Unified Modeling Language (UML) adalah standar industri yang berisi notasi pemodelan perangkat lunak berorientasi objek, terutama ditujukan pada pengembangan perangkat lunak secara cepat (Rapid Application Development) [6] [7] [9]. UML menyediakan berbagai diagram untuk keperluan audien, mulai system analis, system desain, programmer dan pengguna akhir [7].

Konsep pemodelan bisnis dengan UML terdiri dari: Aktor Bisnis, Pekerja Bisnis, use case bisnis, diagram use case bisnis, entitas bisnis dan diagram aktivitas [6].

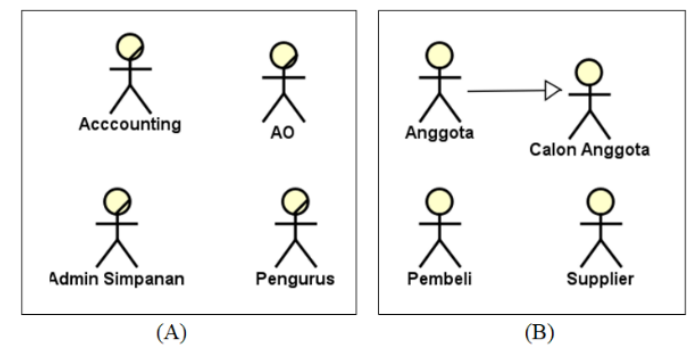

Gambar 1. (A) Pekerja Bisnis (B)Aktor Bisnis

Pekerja bisnis adalah sebuah peran yang berada dalam organisasi, sedangkan Aktor Bisnis adalah sebuah peran yang dilakukan oleh actor di luar organisasi. Contoh Pekerja Bisnis dan Aktor Bisnis dapat dilihat pada Gambar 1. Aktor Accounting, AO, Admin Simpanan dan Pengurus adalah contoh Pekerja Bisnis. Aktor Calon Anggota, Anggota, Pembeli dan Supplier adalah contoh Aktor Bisnis.

Use case bisnis adalah sebuah kelompok dari alur kerja organisasi yang terkait [6] [9]. Sebuah use case bisnis terdiri dari bentuk oval dengan garis miring di sudut kanan bawah dan sebuah teks/label yang merepresentasikan sebuah alur kerja (Gambar 2).
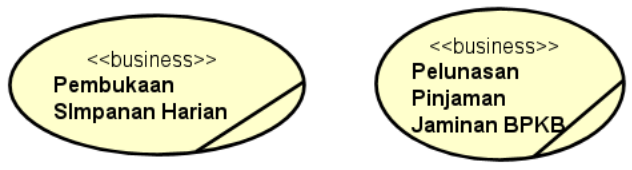

Gambar 2. Contoh Notasi Use Case Bisnis

Penulisan label menggunakan frase yang terdiri dari dua kata, yaitu: kata kerja dan kata benda, contoh: Pembukaan Simpanan Harian.

Sebuah diagram aktivitas menampilkan alur kerja dalam bentuk grafis, urutan langkahlangkah kerja, siapa yang bertanggung jawab terhadap alur kerja dan entitas bisnis yang terlibat dalam alur kerja [6]. 


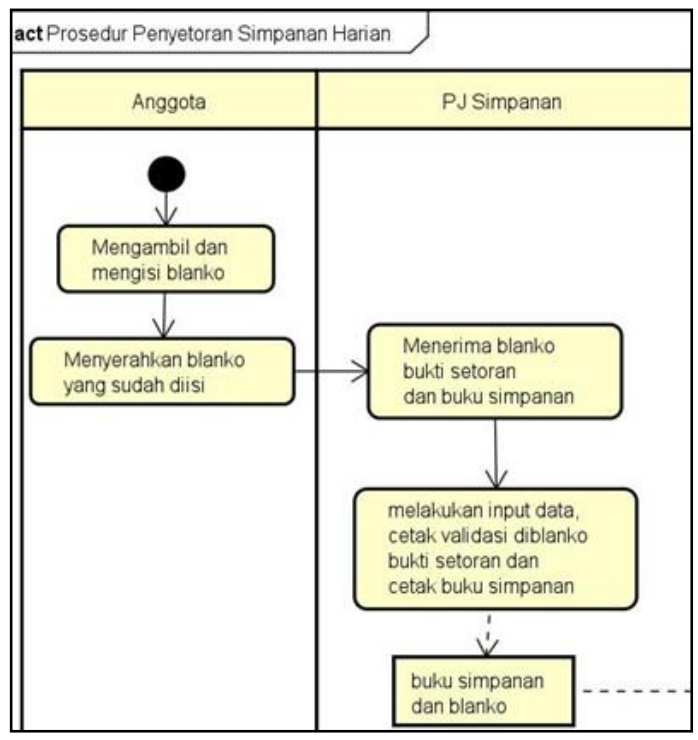

Gambar 3. Contoh Potongan Diagram Aktivitas

Contoh diagram aktivitas dapat dilihat pada Gambar 3. Diagram tersebut menunjukkan 1)swimlane, 2)aktivitas, 3)perpindahan alur dan 4)entitas bisnis.

\section{Pentingnya Pemodelan Bisnis} waktu [6]:

Pemodelan bisnis perlu dilakukan pada

1. Organisasi atau perusahan akan melaksanakan rekayasa ulang proses bisnis.

2. Organisasi atau perusahaan akan melaksanakan rekayasa ulang system.

3. Pengembangan perangkat lunak dengan alur kerja yang kompleks dan melibatkan lintas bagian atau banyak actor.

\section{Pendekatan Pemodelan Bisnis}

Secara umum terdapat dua pendekatan dalam pemodelan bisnis: 1)pemodelan bisnis terpisah dari siklus pengembangan perangkat lunak dan 2)pemodelan system berada dalam siklus pengembangan perangkat lunak [6].

Pemodelan Bisnis diluar siklus iterasi pengembangan perangkat lunak hanya dilakukan $1 \mathrm{x}$ di awal sebelum proses analisis dilakukan. Pemodelan seperti ini menggunakan pemahaman awal yang didapatkan dari proses bisnis yang saat ini berjalan. Sedangkan pemodelan bisnis yang masuk dalam siklus pengembangan perangkat lunak, kegiatannya dilakukan di akhir setelah proses Deploy selesai. Hal ini memungkinkan terjadinya perbaikan dari perangkat lunak yang sudah ada untuk dapat dikembangkan lagi dengan versi yang lebih baik.

Pemodelan bisnis dilakukan secara terpisah dengan iterasi pengembangan perangkat lunak (Gambar 4), dilakukan untuk organisasi atau perusahaan yang sudah memiliki standar proses bisnis. Pendekatan seperti ini memungkinkan pemodelan proses bisnis harus tuntas sebelum memasuki fase pengembangan perangkat lunak.

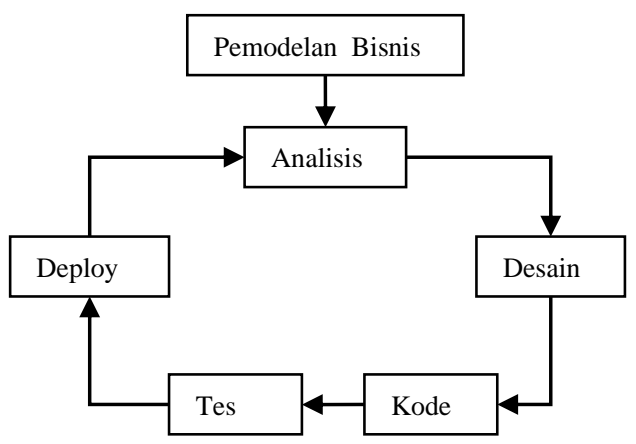

Gambar 4. Pemodelan Bisnis berada di luar Iterasi Pengembangan Perangkat Lunak

Pendekatan pemodelan bisnis yang kedua adalah pemodelan bisnis menjadi satu dalam proses iterasi pengembangan perangkat lunak (Gambar 5).

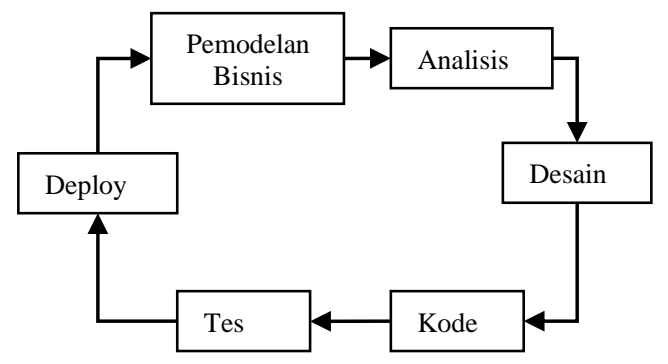

Gambar 5. Pemodelan Bisnis berada dalam Iterasi Pengembangan Perangkat Lunak

Pendekatan kedua ini sesuai untuk perusahaan yang belum memiliki proses bisnis secara baku atau sudah ada proses bisnis tetapi masih memungkinkan terjadi perubahan setelah pengembangan perangkat lunak selesai dan mulai dioperasikan. 


\section{Runut Balik Pemodelan Bisnis dan Siklus Hidup Pengembangan Perangkat Lunak}

Secara umum fase siklus hidup pengembangan perangkat lunak (Software Development Life Cyle - SDLC) adalah: 1)perencanaan, 2)analisis, 3)desain dan 4)implementasi [9] [10].

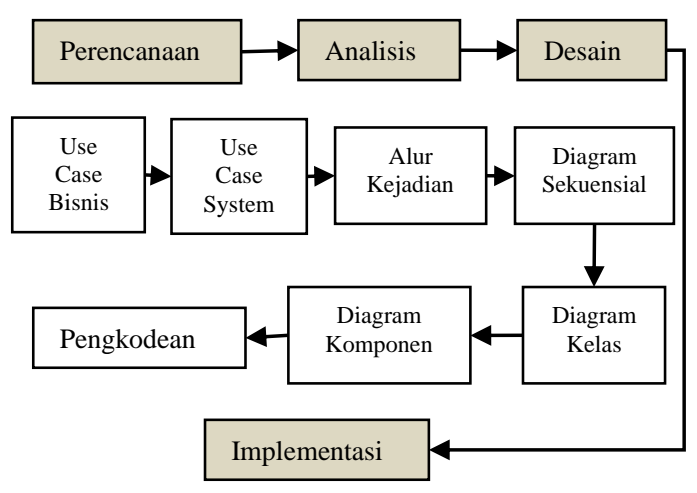

Gambar 6. Runut Balik Pemodelan Bisnis dengan UML dan SDLC

Runut balik (traceability) merupakan factor yang penting untuk diperhatikan dalam pemodelan bisnis yang dilanjutkan ke dalam interasi pengembangan perangkat lunak [6]. Setiap tahapan proses dari use case system sampai dengan pengkodean harus dapat diverifikasi ulang (runut balik) terhadap fase sebelumnya. Contoh: setiap use case system harus bisa dirunut balik ke dalam use case bisnis, dalam arti system yang akan dirancang harus ada kaitannya dengan proses bisnis yang ada pada diagram use case bisnis.

\section{Metode Pemodelan Bisnis}

Secara umum proses pemodelan bisnis dalam penelitian ini menggunakan langkahlangkah sebagai berikut (Gambar 7): finding actor, finding business use case, finding relationships dan creating diagram (diagram use case bisnis dan diagram aktivitas).

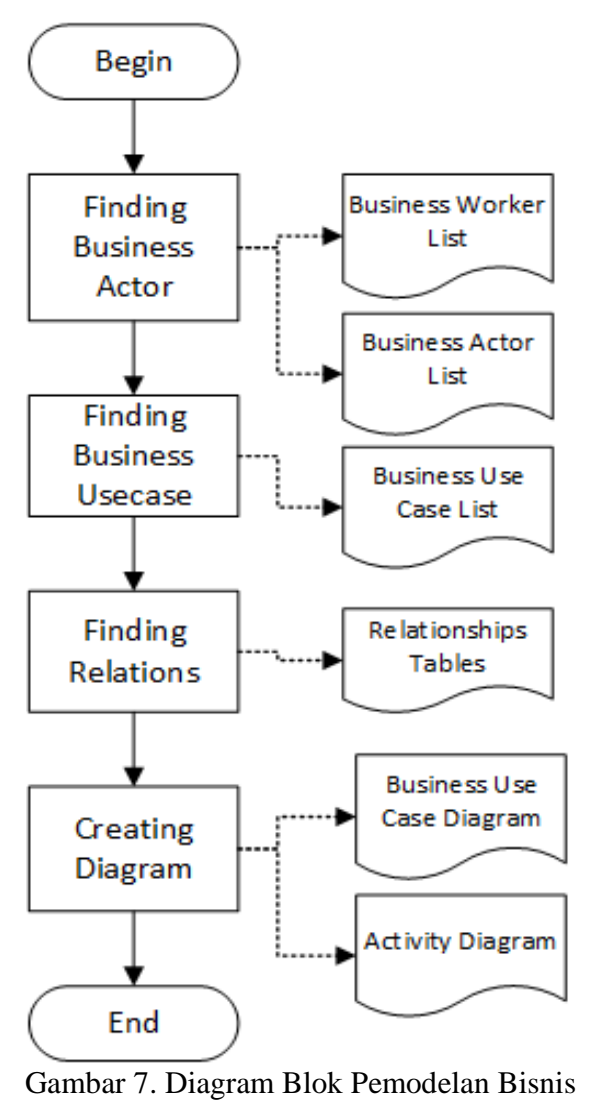

\section{Finding Actor}

Aktor adalah segala sesuatu yang berhubungan dengan [10,9]. Aktor merujuk seseorang, sistem perangkat lunak lain, atau perangkat keras yang berinteraksi dengan sistem untuk mencapai tujuan yang bermanfaat. Beberapa organisasi menggunakan istilah peran pengguna daripada aktor karena mungkin ada beberapa kelompok pengguna yang berbeda yang berinteraksi dengan sistem dengan cara yang sama. Misalnya, kasus penggunaan entri pesanan dapat dilakukan dengan pelanggan atau petugas entri pesanan yang melakukan peran pengguna.Finding Actor adalah proses menemukan actor yang terlibat dalam sebuah system [6].

Dalam penelitian ini aktor yang terlibat pada system Rekayasa Perangkat Lunak UKM Koperasi telah dibuatkan daftar actor pada Tabel 1. Dimana actor dibagi menjadi 2 jenis, yaitu business actor untuk pelaku yang berada di luar internal perusahaan yaitu Calon Anggota dan Anggota Koperasi. Sedangkan business worker 
Teguh Sutanto, dkk/ Journal of Technology and Informatics (JoTI), Vol.2, No.2, April 2021, Hal 5664

adalah actor atau pelaku yang berada/bekerja langsung pada internal perusahaan.

Proses pencarian actor dilakukan dengan cara: 1)wawancara, 2)mempelajari dokumentasi Unit UKM, dan 3)membaca buku panduan pengoperasian Aplikasi Unit UKM. Hasil pencarian actor dapat dilihat pada Tabel 1 .

\begin{tabular}{lll}
\multicolumn{3}{c}{ Tabel 1. Daftar Aktor } \\
\hline ID & ACTOR NAME & STEREO TYPE \\
\hline BA1 & Calon Anggota & Business Actor \\
BA2 & Anggota & Business Actor \\
BW1 & PJ Simpanan & Business Worker \\
BW2 & PJ Pinjaman & Business Worker \\
BW3 & AO & Business Worker \\
BW4 & Kabag & Business Worker \\
BW5 & Kasie & Business Worker \\
BW6 & Kasir & Business Worker \\
BW7 & Pengurus & Business Worker \\
BW8 & Accounting & Business Worker \\
BW9 & Juru Taksir & Business Worker \\
\hline
\end{tabular}

Ditemukan ada 11 actor yang terdiri dari 2 Business Actor dan 9 Business Worker. Berdasarkan 11 actor tersebut maka langkah berikutnya adakah mencari proses bisnis apa saja yang dilakukan oleh setiap actor.

\section{Finding Business Use Case}

Berdasarkan hasil survey dan mempelajari dokumen yang ada pada koperasi maka ditemukan ada 22 proses bisnis. Proses bisnis tersebut akan dijadikan kandidat use case bisnis seperti yang terlihat pada Tabel 2 .

\begin{tabular}{cll}
\hline UCB & USE CASE BUSINESS & \multicolumn{1}{c}{ MAIN } \\
ACTOR
\end{tabular}

\section{Finding Relationship}

Setiap proses bisnis yang ada harus ada satu actor yang mengawalinya. Tabel 2 menunjukkan use case bisnis beserta main actor. Main actor adalah actor yang mengalami terjadinya use case bisnis.

Tabel 3. Relasi Use Case Bisnis dengan Aktor

Tabel 2. Daftar Use Case Bisnis

\begin{tabular}{|c|c|c|c|c|c|c|c|c|c|c|c|c|c|c|}
\hline & \multirow{2}{*}{ ID } & \\
\hline $\begin{array}{l}\text { UCB } \\
\text { ID }\end{array}$ & USE CASE BUSINESS & $\begin{array}{l}\text { MAIN } \\
\text { ACTOR }\end{array}$ & & 死 & m & $\sum_{\infty}^{3}$ & $\sum_{\infty}^{1}$ & $\hat{m}$ & $\sum_{\infty}^{+}$ & m & $\sum_{\infty}^{\infty}$ & $\hat{3}$ & $\sum_{n}^{\infty}$ & $\hat{n}$ \\
\hline UC1 & Pendaftaran Anggota & $\begin{array}{l}\text { Calon } \\
\text { Anggota }\end{array}$ & こ & 2 & 0 & 1 & 0 & 0 & 0 & 1 & 1 & 0 & 1 & 0 \\
\hline $\mathrm{UC2}$ & Pengunduran Diri Anggota & Anggota & & & & & & & & & & & & \\
\hline UC3 & $\begin{array}{l}\text { Pengajuan Pinjaman Agunan } \\
\text { Sertifikat BPKB }\end{array}$ & Anggota & న్ & 0 & 2 & 1 & 0 & 0 & 0 & 1 & 1 & 0 & 1 & 0 \\
\hline UC4 & $\begin{array}{l}\text { Persetujuan Pinjaman Agunan } \\
\text { Sertifikat - BPKB }\end{array}$ & Kasie & $\tilde{\omega}$ & 0 & 2 & 1 & 0 & 1 & 0 & 1 & 0 & 0 & 0 & 0 \\
\hline UC5 & $\begin{array}{l}\text { Realisasi Pinjaman Agunan } \\
\text { Sertifikat - BPKB }\end{array}$ & Anggota & Бี & 0 & 0 & 0 & 0 & 1 & 1 & 2 & 1 & 0 & 0 & 0 \\
\hline UC6 & $\begin{array}{l}\text { Pengajuan Pinjaman } \\
\text { Multiguna Jaminan Emas }\end{array}$ & Anggota & & & & & & & & & & & & \\
\hline
\end{tabular}




\begin{tabular}{|c|c|c|c|c|c|c|c|c|c|c|c|}
\hline \multirow{2}{*}{ ID } & \multicolumn{11}{|c|}{ ACTOR ID } \\
\hline & ব্ড & वै & 店 & 莕 & 艿 & 营 & 言 & 总 & 竞 & $\sum_{n}^{\infty}$ & 高 \\
\hline 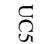 & 0 & 2 & 0 & 0 & 1 & 1 & 1 & 1 & 1 & 1 & 0 \\
\hline$\check{\Omega}$ & 0 & 2 & 0 & 1 & 0 & 0 & 1 & 0 & 0 & 0 & 1 \\
\hline కె & 0 & 0 & 0 & 1 & 0 & 1 & 2 & 0 & 1 & 0 & 0 \\
\hline ટี & 0 & 2 & 0 & 0 & 1 & 1 & 1 & 1 & 1 & 1 & 0 \\
\hline కุర & 0 & 2 & 0 & 1 & 0 & 0 & 1 & 0 & 0 & 0 & 0 \\
\hline 气̊ & 0 & 0 & 0 & 1 & 0 & 1 & 2 & 0 & 1 & 0 & 0 \\
\hline$\stackrel{\varrho}{\varrho}$ & 0 & 2 & 0 & 1 & 1 & 1 & 1 & 1 & 1 & 1 & 0 \\
\hline$\frac{\check{2}}{\frac{2}{N}}$ & 0 & 2 & 1 & 0 & 1 & 0 & 1 & 1 & 0 & 0 & 0 \\
\hline$\stackrel{\check{\Omega}}{\tilde{\omega}}$ & 0 & 2 & 0 & 1 & 1 & 0 & 1 & 1 & 1 & 0 & 0 \\
\hline$\stackrel{\check{\Omega}}{\check{\perp}}$ & 0 & 2 & 1 & 0 & 0 & 1 & 1 & 0 & 0 & 0 & 0 \\
\hline$\frac{\tilde{\Omega}}{\tilde{U}}$ & 0 & 0 & 0 & 0 & 0 & 0 & 0 & 0 & 0 & 0 & 0 \\
\hline $\begin{array}{l}\tilde{\Omega} \\
\frac{2}{a}\end{array}$ & 0 & 0 & 0 & 0 & 0 & 0 & 0 & 0 & 0 & 0 & 0 \\
\hline$\stackrel{\varrho}{3}$ & 0 & 0 & 0 & 0 & 0 & 0 & 0 & 0 & 0 & 0 & 0 \\
\hline$\stackrel{\check{2}}{\infty}$ & 0 & 0 & 1 & 0 & 0 & 0 & 1 & 1 & 0 & 1 & 0 \\
\hline$\frac{\complement}{2}$ & 0 & 0 & 0 & 0 & 0 & 0 & 0 & 0 & 0 & 0 & 0 \\
\hline స్ & 0 & 2 & 1 & 0 & 0 & 1 & 1 & 0 & 0 & 1 & 0 \\
\hline
\end{tabular}

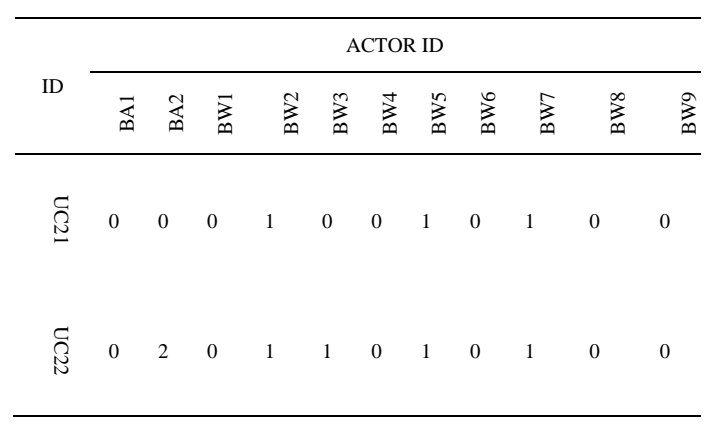

Tabel 1 menunjukkan Daftar Aktor yang terlibat pada pemodelan bisnis UKM Koperasi. Tabel 2 menunjukkan Daftar Use Case Bisnis yang terjadi pada Pemodelan Bisnis UKM Koperasi. Sedangkan Tabel 3 merupakan hasil relasi/hubungan antara tabel 1 dan tabel 2. Tabel relasi tersebut merepresentasikan relasi asosiasi antara use case bisnis dengan actor. Jika ada relasi antara use case bisnis dengan actor maka pada baris dan kolom yang sesuai diisi dengan nilai 1 , jika tidak ada relasi diisi dengan angka 0 . Jika sebuah actor mengawali terjadinya use case bisnis maka diberikan nilai 2 .

\section{HASIL DAN PEMBAHASAN}

Berdasarkan tabel relasi (Tabel 3) maka dilanjutkan dengan proses pembuatan diagram use case bisnis. Hasil diagram bisnis use case dapat dilihat pada Gambar 8. Pada gambar tersebut terlihat terdapat 22 use case yang terhubung dengan aktor-aktornya. Relasi antara use case dan aktor telah ditetapkan berdasarkan Tabel 3. Contoh relasi antara UC1 Pendaftaran Anggota yang dihubungkan dengan Aktor BA1 Calon Anggota, dimana Aktor BA1 Calon Anggota mengawali terjadinya aksi/kegiatan untuk melakukan Proses Pendaftaran Anggota. Use Case Pendaftaran Anggota juga berelasi dengan BW1 PJ Simpanan, BW5 Kasie, BW6 Kasir, dan BW8 Accounting yang akan nantinya juga berlanjut untuk UseCase kegiatan Peminjaman dan Simpanan. 


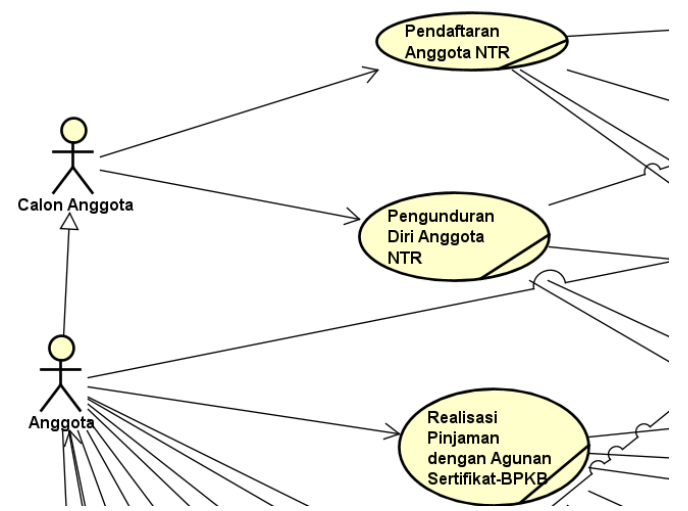

Gambar 8. Potongan Diagram Use Case Bisnis Unit UKM

Diagram use case bisnis Unit UKM dapat menggambarkan proses bisnis utama dalam Unit UKM lengkap dengan relasi asosiasi antara aktor dengan use case bisnis dan relasi generalisasi antara antor dengan aktor.

Tabel 4. Aktor dan Total Relasi

\begin{tabular}{clr}
\hline No & \multicolumn{1}{c}{ Actor } & $\sum \mathrm{R}$ \\
\hline 1 & Anggota & 24 \\
2 & Kasie & 21 \\
3 & Kasir & 9 \\
4 & PJ Pinjaman & 8 \\
5 & AO & 8 \\
6 & Kabag & 8 \\
7 & Pengurus & 8 \\
8 & Accounting & 8 \\
9 & PJ Simpanan & 7 \\
10 & Calon Anggota & 2 \\
11 & Juru Taksir & 1 \\
\hline
\end{tabular}

Setelah relasi asosiasi antara use case bisnis dan actor, maka dapat dihitung jumlah relasi yang terjadi (Tabel 4). Tabel 4 menunjukan bahwa aktor Anggota memiliki relasi yang paling banyak diantara 10 aktor lainya, hal ini menunjukkan bahwa Anggota sangat berkepentingan dengan proses bisnis pada Unit UKM Koperasi Wanita Setia Bhakti Wanita Jawa Timur. Berdasarkan hal tersebut maka Unit EDP dapat memprioritaskan use case bisnis yang berelasi dengan Anggota harus dilakukan iterasi pengembangan perangkat lunak.

\section{Diagram Aktivitas}

Berdasarkan diagam use case bisnis seperti maka langkah berikutnya adalah membuat diagram aktivitas untuk setiap use case bisnis. Diagram aktivitas berisi alur kerja proses bisnis yang diawali oleh aktor utama. Berdasarkan hasil finding use case bisnis yang menghasilkan 22 use case bisnis maka diagram aktivitas yang harus dibuat adalah sebanyak 22 diagram. Contoh diagram aktivitas untuk use case bisnis Pengajuan Pinjaman dengan Agunan Sertifikat/BPKB dapat dilihat pada Gambar 9.

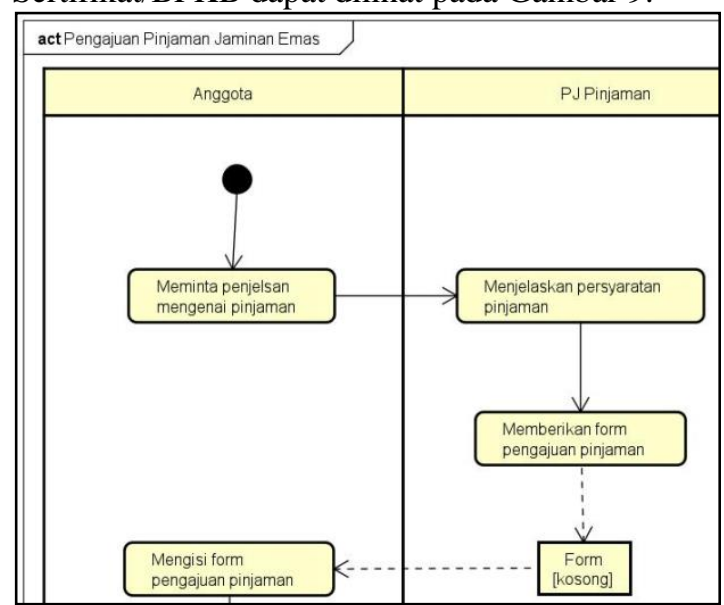

Gambar 9. Contoh Potongan Diagram Aktivitas Pengajuan Pinjaman

Diagram aktivitas pada Gambar 9 menunjukkan bahwa alur proses pengajuan pinjaman dengan jaminan sertifikat/BPKB melibatkan 3 aktor. Jumlah dan nama aktor yang terlibat diperoleh dari hasil pencarian relasi (Tabel 3). Nama aktor yang terlibar harus menjadi swimlane pada diagram aktivitas. Swinlane menunjukkan siapa yang bertanggung jawab atas proses yang sedang berjalan.

Diagram akvitas juga memberikan informasi penting bagi Tim Pengembang yaitu adanya objek bisnis. Dengan mengetahui objek bisnis maka Tim Pengembang dapat menentukan Tabel dan Laporan yang dibutuhkan atau dihasilkan oleh sebuah proses.

\section{Rekomendasi Pemilihan Pendekatan Pemodelan Bisnis.}

Setelah melaksanakan pemodelan bisnis pada Unit UKM maka berikut ini adalah faktorfaktor yang dapat digunakan sebagai bahan pertimbangan pemilihan pendekatan pemodelan bisnis dalam kaitannya dengan pengambangan prangkat lunak: 
1. Unit UKM sudah memiliki mekanisme pelayanan Anggota yang sudah baku.

2. Unit UKM sudah memiliki System UKM yang digunakan dalam menjalankan proses bisnis.

3. Unit UKM bermaksud mengganti basis aplikasi dari desktop menjadi web.

4. Unit UKM bermaksud menerapkan pembagian hak dan wewenang user dalam menjalankan system berdasarkan prosedur yang sudah baku.

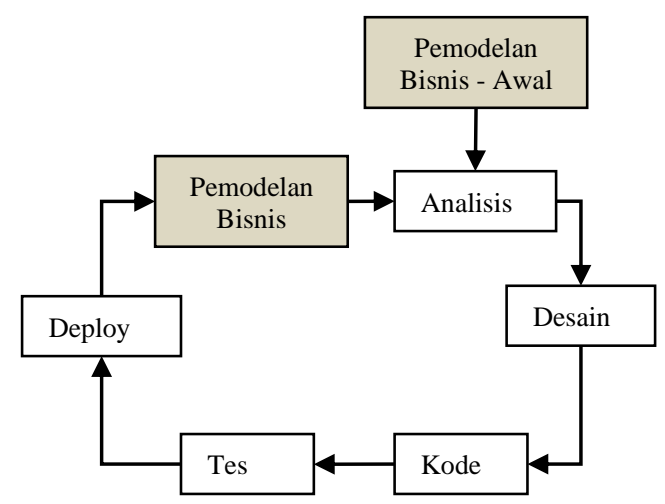

Gambar 10. Rekomendai Pendekatan Pemodelan Bisnis dalam Rekayasa Ulang Sistem UKM

Berdasarkan faktor di atas maka pendekatan pemodelan bisnis yang sesuai dalam rangka rekayasa ulang System UKM adalah pendekatan gabungan antara pemodelan bisnis yang terpisah dari siklus pengembangan perangkat lunak dengan pendekatan pemodelan bisnis dalam siklus pengembangan perangkat lunak (lihat Gambar 10). Pada gambar tersebut terlihat bahwa langkah awal adalah melakukan tahapan Pemodelan Bisnis Awal, kemudian melakukan proses análisis - desain pengkodean - Tes - Deploy - serta Pemodelan Bisnis Akhir.

Pemodelan bisnis dilaksanakan minumum 2 kali:

1. Pemodelan Bisnis Awal

Pemodelan ini dilakukan di luar iterasi pengembangan perangkat lunak, karena Unit UKM sudah memiliki proses bisnis yang sudah baku dan memiliki System UKM. Hasil pemodelan bisnis awal ini akan menjadi masukan bagi proses pengembangan perangkat lunak.

2. Pemodelan Bisnis Dalam Iterasi
Pemodelan bisnis dalam iterasi perlu dilakukan karena terjadi perubahan pada System UKM sehingga mengakibatkan perubahan pada alur kerja Unit UKM. Dengan adanya perubahan alur kerja maka perlu dilakukan pemodelan bisnis yang akan berpengaruh terhadap proses análisis dan seterusnya.

\section{KESIMPULAN DAN SARAN}

Penelitian ini telah menghasilkan diagram use case bisnis dan diagram aktivitas. Berdasarkan diagram use case bisnis (Gambar 8) terlihat bahwa Unit UKM memiliki 22 aktivitas bisnis yang berinteraksi dengan 11 aktor. Jumlah use case bisnis dan jumlah aktor sudah dijelaskan dan dapat dilihat pada Tabel 2 dan Tabel 4.

Berdasarkan 22 use case bisnis yang dilanjutkan dengan 22 diagram aktivitas maka Tim Pengembang Aplikasi dapat melakukan proses analisa kebutuhan sistema dengan cara memilih aktivitas yang dapat dikerjakan secara elektronik atau komputerisasi untuk dijadikan diagram use case system.

\section{DAFTAR PUSTAKA}

[1] Peran Koperasi Dalam Meningkatkan Perekonomian Masyarakat Nelayan: Perspektif Modal Kerja, Jurnal Akademi Akuntansi, vol. vol 3 no 1 , pp. 118-132, 2020.

[2] S. Semaun, Eksistensi Koperasi Wanita Dalam Meningkatkan Pendapatan Masyarakat, Jurnal Al-Maiyyah, Volume 11 No. 2 Juli - Desember 2018, pp. 190-213, 2018.

[3] R. Rosita, Pengaruh Pandemi Covid-19 Terhadap UMKM, Jurnal Lentera Bisnis, vol. Volume 9 No 2, pp. 109-121, 2020.

[4] W. C. Anggraeni, W. P. Ningtiyas y N. M. Alimah, Kebijakan Pemerintah Dalam Pemberdayaan UMKM Di Masa Pandemi Covid-19 Di Indonesia, Journal of Government and Politics (JGOP), Vols. \%1 de \%247-65, p. Vol. 3 No. 1, 2021.

[5] W. Suharso y D. A. Pradhipta Mualim, Rekayasa Ulang Sistem Permintaan Informasi Pada Kejaksaaan Negeri Batu, Jurnal Instek, vol. Vol.3 No.2 Oktober 
Teguh Sutanto, dkk/ Journal of Technology and Informatics (JoTI), Vol.2, No.2, April 2021, Hal 5664

2018, pp. 272-280, 2018.

[6] W. Boggs y M. Boggs, Mastering UML with Rational Rose 2002, Alameda: SYBEX, 2002.

[7] P. Sulistyorini, Pemodelan Visual dengan Menggunakna UML dan Rational Rose, Jurnal Teknologi Informasi Dinamik, vol. XIV, pp. 23-29, 2009.

[8] B. Rumpe, Modeling with UML Language, Concepts, Methods, Switzerland: Springer International, 2016.

[9] A. Dennis, B. H. Wixom y R. M. Roth, System Analysis and Design Fifth Edition, NY: John Wiley \& Sons, Inc., 2012.

[10] B. Unhelkar, Software Engineering with UML, Boca Raton: CRC Press, 2018. 